\title{
Local Office Rent Dynamics
}

\section{A Tale of Ten Cities}

\author{
Dirk Brounen • Maarten Jennen
}

Published online: 7 May 2008

(C) The Author(s) 2008

\begin{abstract}
This study applies rent adjustment models for ten major European office markets. We capture long-run equilibrium relationships of demand and supply variables and their short-term corrections in a two equation error correction model. We test whether the local nature of office markets makes a model based on national economics inaccurate if local and national markets do not move in tandem. For this we employ a unique dataset, which includes both disaggregated and national variables to model changes in real prime rents for a group of premier and second tier office market cities across Europe for the period 1990-2006. We explicitly compare results that are derived from models that include different levels of geographic aggregation. Results of the two stage error correction model indicate that international office rents adjust to short-run changes in office related economic activity, lagged rent changes, and to the deviation of rents from their long-run values. At the same time our results offer no proof that error correction mechanism models for office rents improve significantly by specifying economic growth figures beyond the national aggregated level for the cities included in our analysis.
\end{abstract}

Keywords Office rents · Error correction models · Local markets ·

International markets

\section{Introduction}

Understanding rent dynamics across real estate cycles has been at the heart of the real estate literature ever since Blank and Winnick (1953) provided a simple theoretical framework in which residential rent changes were modeled as a function of vacancy rates. Shilling et al. (1987) were among the firsts to apply this model to explain local US office rents, while Wheaton and Torto (1988) estimated the model

D. Brounen $\cdot$ M. Jennen $(\bowtie)$

Finance Group, Rotterdam School of Management Erasmus University, Room T09-43, Burg.

Oudlaan 50, 3062 PA Rotterdam, The Netherlands

e-mail: mjennen@rsm.nl 
for the aggregate US office market. In this paper we use an error correction model in line with Hendershott et al. (2002b) to model office rents for ten cities across five European countries over the period 1990-2006. We extent existing methodology and findings by examining an international panel of cities, and by incorporating two geographic aggregation levels of economic data. To model changes in real prime office rents we use national economic and employment series and the most detailed local versions of these data available for European cities; the Nuts 3 level which corresponds to Départements in France, Kreise in Germany, Corop-regions in the Netherlands, Provincias in Spain, and Counties in the UK. ${ }^{1}$ Through the analysis of premier and second ties office market cities in each country we are able to test whether local data availability is more important for smaller cities that make up less of the national aggregate than for the premier office markets of each country.

The concentration of office centers of variable size and importance in various countries within a relatively small geographical area makes the exploration of return determinants for European office markets, as executed in this study, an interesting case. To facilitate the analysis of the local nature of the markets we selected the primary and a secondary office market for; the United Kingdom, Spain, Germany, France, and The Netherlands. Based on this selection we constructed a dataset consisting of London and Glasgow; Madrid and Barcelona; Frankfurt and Düsseldorf; Paris and Lyon; and Amsterdam and Rotterdam. During our sample period the average correlation between real prime rent changes of pairs of first and second tier office cities within one country equals only 0.36 . Hence, there is little reason, a priori, to expect that national economic growth figures are accurate for modeling changes in real prime rents given that changes in this variable differ strongly between cities within one country.

Results of a two stage error correction model indicate that office rents adjust to short-run changes in office related economic activity, lagged changes in rents, and to the deviation of rents from their long-run values. We vary the definition of office related economic activity using service employment and gross domestic product (GDP), but find only marginal differences in model performance. Furthermore, our results offer no proof that error correction mechanism (ECM) models for office rents improve significantly by specifying economic growth figures beyond the national aggregated level. Office markets of large cities are driven by economic developments that reach beyond city boundaries due to the concentration of (inter)national conglomerates in large cities, so it is no direct surprise that changes in GDP on a local level do not perform better in explaining local office rents. However, this would not hold for employment figures. Service sector employment on a local level should influence local demand for office space and therefore changes in office rents. However, due to the high correlation between local and national level changes in service sector employment we find no significant differences in model fit.

The remainder of the paper continues as follows. "Modelling Office Rents" discusses relevant literature and the methodology we use in the analysis. "European Office Market Data" presents the data. In "Regression Results" we discuss the findings. "Conclusion and Discussion" concludes.

\footnotetext{
${ }^{1}$ Nuts stands for 'Nomenclature of Territorial Units for Statistics' in French. For a fuller discussion of spatial aggregation definitions in Europe we like to refer to Ciccone (2002).
} 


\section{Modelling Office Rents}

Over the last two decades numerous contributions provided valuable new insights into the determinants of office rents. However, the vast majority of these studies links local office rents to excess vacancy levels or national aggregated economic data and only a small portion of this literature looks outside the US. A focus on national aggregated data is surprising given that office markets are considered local. This local focus is due to the high proportion of office use which is derived from local demand (Hanink 1996). A model based on aggregate data provides an accurate picture of the determinants of office returns only if all variables move in the same direction for each of the individual local markets. Early work by Hekman (1984) showed that office rents adjust in response to both local and national economic conditions which makes office studies based on national data potentially inaccurate. This is due to a shift/share problem in which the shift component is related to different compositions of employment sectors across cities and unequal growth rates of these sectors within cities. The share component is a result of different growth rates of cities themselves (Hekman 1984). We overcome this pivotal problem by employing a dataset which includes disaggregated, or local, variables to study local office markets and compare results with models based on national economic data.

Office rent literature has evolved differently across continents. The US office literature focuses on vacancy rates and models office rents as a function of deviations from the natural vacancy rate that is required to clear the market. Wheaton and Torto (1988) use US national time series data on office rents and vacancy rates and find that excess vacancy rates affect real rents, while the natural vacancy rate is influenced by variables such as the local tenant structure, average lease terms in the market, expected absorption rates and operating costs. Hendershott (1996), in a study of the Sydney office market, introduced a more general rent adjustment model in which changes in real rents are a function of vacancy and rent deviations from equilibrium levels. Eq. 1 shows the basic form of this type of real estate rent modelling:

$$
\% \Delta R_{t}=\alpha\left(v_{t}^{*}-v_{t-1}\right)+\beta\left(R_{t}^{*}-R_{t-1}\right)
$$

where $v_{t}^{*}$ is the estimated natural vacancy rate, $v_{t-1}$ the lagged vacancy rate, $R_{t}^{*}$ the time-varying equilibrium real office rent, and $R_{t-1}$ the lagged rent level. $R^{*}$ is a function of the depreciation rate, operating expenses, the real risk free interest rate, the risk premium and real replacement costs. Estimates for Sydney (Hendershott 1996) and London (Hendershott et al. 1999) show that the determinants of $R^{*}$ can differ substantially across markets. The applicability of office rent models in line with Eq. 1 for our study of European cities is limited due to the relative subjective determination of the variables that constitute $R^{*}$. McDonald (2002) applies an alternative rent equation on the data from the Hendershott et al. (1999) study. The model is based on McDonald (2000) and includes separate equations for demand for occupied space and demand for vacant space. Demand for occupied space $(Q)$ is:

$$
Q_{t}=Q_{0}-b_{1} R_{t}+b_{2} E_{t}
$$


where $Q$ is a function of rent per square foot $(R)$ and a measure for office employment $(E)$. The demand for vacant space is a positive function of mobility in the market and negatively influenced by the office rent level. At a given level of mobility of office employment in the market the demand for vacant space $(V)$ equals:

$$
V_{t}=V_{0}-\beta R_{t} .
$$

Rearranging Eqs. (2) and (3) and solving for $R$ leads to a reduced form equilibrium rent equation where rent is a function of office employment, the total stock of space $(S)^{2}$ and the parameters shown in Eqs. 2 and 3.

$$
R_{t}=\frac{\left(Q_{0}+V_{0}\right)}{\left(\beta+b_{1}\right)}+\frac{b_{2}}{\left(\beta+b_{1}\right)} E_{t}-\frac{1}{\left(\beta+b_{1}\right)} S_{t} .
$$

McDonald (2002) finds that equilibrium rent is a positive function of the level of employment in office occupying industries and a negative function of stock of space.

While US researchers have been building upon a long history of office vacancy and rental data, European office market research has generally been hindered by data availability constraints. In particular the unavailability of supply side variables directed European research towards reduced form equations, and tests of a wide array of possible office rent determinants. The general model specification for reduced form models as applied in European office markets typically includes a vector of economic demand side variables in combination with, where available, a vector of real estate supply side variables. Widely used demand side variables are changes in GDP, service sector employment, lagged short-term interest rates and unemployment rates. One of the earliest works in this respect is Giussani et al. (1992) who studied ten European cities and use a model consisting of demand side variables over a nine year period starting in 1983. Although the influence of supply side variables on changes in office rents is acknowledged, actual inclusion is left out of the analysis due to data constraints. D'Arcy et al. (1997) study office rent changes of 22 European cities over the period 1982-1994 and use changes in national GDP and short-term interest rates as explanatory variables. Extensions of the model with office market size and measures of economic growth and change in the local economy did not provide additional insights. Advances in data availability for European commercial real estate have allowed for the inclusion of supply side variables in office market research. D'Arcy et al. (1999) use GDP, service sector employment and stock of office floor space for the Dublin office market during the 1970-1997 period and find that changes in real GDP lagged one period and changes in the stock of office space lagged three periods are the key determinants of changes in rental values. De Wit and van Dijk (2003) study determinants of direct office investment returns for 46 major office districts across Asia, Europe and the United states. Demand side variables included in their panel data model are changes in GDP/gross metropolitan product, unemployment rates, and inflation. Supply side variables are change in office stock and change in vacancy rates.

\footnotetext{
${ }^{2}$ Total stock of office space $(S)$ equals per definition demand for occupied space $(Q)$ plus demand for vacant space $(V)$.
} 
Hendershott et al. (2002a, b) elegantly combine the two continental strands of office literature in an ECM. In this paper we apply this methodology for a panel of international cities of different importance to the national economy and apply both national and local economic activity variables. The inclusion of premier and secondary office cities and application of national and the most detailed local data allows for a test of the shift-share issue in European office market research. The model is derived as a reduced-form estimation equation for the occupied office space and does not require estimates for variables such as depreciation rates and operating expenses. Demand for space $(D)$ is modelled as a function of real effective rent $(R)$ and a measure for office demand related economic activity $(E A):^{3}$

$$
D=\lambda_{0} R^{\lambda_{1}} E A^{\lambda_{2}}
$$

where the $\lambda_{I}$ 's are constants with the price elasticity, $\lambda_{1}$, expected to be negative and $\lambda_{2}$, the income elasticity, positive. Per definition the demand for office space, a function of $D$ and $E A$ as in Eq. 5, equals the product of available office space $(S U)$ and one minus the prevailing office vacancy rate $(v)$ :

$$
D(R, E A) \equiv(1-v) S U
$$

Equation 6 shows that real estate markets clear towards equilibrium through changes in rents and vacancy levels. Including contemporaneous vacancy rates in the rent equation leads to misspecification as vacancy rates are not exogenous in the equilibrium rent model. For this reason we use a separate equation to model the vacancy rate which subsequently enters the error correction model as a fitted variable $(\hat{v})$. We model vacancy rates with a simple autoregression model analogous to Grenadier (1995). After testing different autoregression functions we find that an AR(2) model provided the best fit for the ten cities that form the basis of our study. Adjusted $R^{2}$ for the ten cities included in our analysis of the AR(2) model over the period 1990-2006 range from 0.54 to 0.87 with an average of 0.75 .

Rearranging Eqs. 5 and 6 by logarithmic transformation, including fitted vacancy rates, and solving for real rent levels results in the long run rent specification identified in Eq. 7:

$$
\ln R_{t}=\gamma_{0}+\gamma_{1} \ln E A_{t}+\gamma_{2} \ln \left\lfloor\left(1-\hat{v}_{t}\right) * S U_{t}\right\rfloor+u_{t}
$$

Economic activity is proxied in the literature with variables such as retail sales and consumer expenditure for retail space while demand for office space was modelled with value added of office related industries, finance, insurance and real estate employment, and general GDP. Inclusion of different economic activity measures in a single equation is prone to multicollinearity issues leading to insignificant coefficients in multiple regression analysis (see for example Giussani et al. 1992; Gordon et al. 1996; and de Wit and van Dijk 2003). ${ }^{4}$ Supply side variables in Eq. 7 are less frequent in empirical research for European real estate due to limited

\footnotetext{
${ }^{3}$ Demand for office space, as demonstrated by the European office modeling strand, is influenced by changes in economic factors such as GDP, value added for office related industries and employment in office occupying industries.

${ }^{4}$ Inclusion of principal component analysis with orthogonalized variables overcomes the multicollinearity issue but limits the insight in rent drivers as the true nature of the principal components is unclear.
} 
attention from local professionals for gathering supply side data. Hendershott et al. (2002a) include a supply side variable in their model of the London office market but find insignificant results for changes in office supply. Similar results were found in the Hendershott et al. (2002b) paper for a panel of regions in the UK excluding London. Hendershott et al. (2002b), lacking data on vacancy rates, use an alternative specification of Eq. 7. In this equation the effect of vacancy rates on equilibrium rent levels is embedded in the error term resulting in a rent specification analogous to the specification in McDonald $(2000,2002)$ where rent is a function of employment and office supply.

The ECM we use to model changes in real prime rents in a panel data approach estimates long-run equilibrium relationships and short-term corrections. Due to frictions, as already indicated by Wheaton (1987) in a study of the cyclic behaviour of the US office market, office markets usually do not clear within short-run periods of time. We measure this imbalance as the residual of Eq. 7 and subsequently use the residual as a factor in the short-run model. The rationale behind this inclusion is that the residual reflects the disequilibrium in the market and that disequilibria in office markets are leveled during consecutive periods.

The disequilibrium measure can be used in the short-run model only if the trending variables used in Eq. 7 are cointegrated. Cointegration is present if the residuals of a function of the level data are stationary. We test for a unit root, and subsequent non-stationarity in the error term, with a Levin et al. (2002) test. Taking differences of Eq. 7, excluding the residual, and adding the lagged residual, leads to the short-run rent adjustment model as depicted in Eq. 8 with an added lagged dependent variable to allow for the autoregression present in the change in real rent series. 5

$$
\Delta \ln R_{t}=\alpha_{0}+\alpha_{1} \Delta \ln E A_{t}+\alpha_{2} \Delta \ln \left[\left(1-\hat{v}_{t}\right) * S U_{t}\right]+\alpha_{4} u_{t-1}+\alpha_{5} \Delta \ln R_{t-1}+\varepsilon
$$

According to Eq. 8 office rents react to short-run changes in causal variables, lagged residuals of the long-run model, as a reflection of market imbalances and lagged changes in office rents. ${ }^{6}$

\section{European Office Market Data}

With the exception of London, research on European office markets has always been hampered by availability of proper property data. Fortunately, as time progressed databases grew, enabling international research projects to uncover the driving forces behind European commercial property dynamics. The data we apply in this study

\footnotetext{
${ }^{5} \mathrm{~A}$ regression of rent changes for all cities on one period lagged rent changes results in a coefficient of 0.32 which is significant at the $1 \%$ level.

${ }^{6}$ Modeling results lead to expectations that $\alpha 0$ equals zero, $\alpha_{1}$ and $\alpha_{5}$ are positive, and $\alpha_{2}, \alpha_{3}$, and $\alpha_{4}$ are negative. $\alpha_{4}$ indicates the speed of adjustment towards equilibrium. If $\alpha_{4}$ equals -1 there is full equilibrium restoration after one period while $\alpha_{4}$ between zero and -1 or larger than -1 indicate partialand overadjustment respectively.
} 
includes annual office market data offered by Jones Lang LaSalle dating back to 1990. Our dataset covers prime rents, existing stock of office space, and vacancy rates for the two most important office cities from five different countries. Prime office rents represent the top open-market rent that could be expected for a notional office unit of the highest quality and specification in the best location in a market, as at the survey date. The rent quoted normally reflects prime units of over $500 \mathrm{~m}^{2}$ of lettable floor space, which excludes rents that represent a premium level paid for a small quantity of space. The prime rents reflect an occupational lease that is standard for the local market. It is a face rent, that does not reflect the financial impact of tenant incentives, and excludes service charges and local taxes. It represents Jones Lang LaSalle's market view and is based on an analysis/review of actual transactions for prime office space, excluding any unrepresentative deals. Where an insufficient number of deals have been made for prime office space, an assessment of rental value is provided by reference to transactions generally in that market adjusted accordingly to equate to prime. The selection of countries is driven by data availability and city suitability. Office markets that are clearly driven by public sector employment such as Brussels in Belgium, which exhibits a strong European Union impact, and The Hague, as the government residence of the Netherlands, were excluded. We only include countries that offer us full data coverage for both the office market and economic parameters and that enable a premier and secondary city analysis. The premier office markets from the countries included in our study are London, Madrid, Frankfurt, Paris, and Amsterdam. The selection of second tier office market is based on the criterion that the office markets are large enough to house substantial office occupying corporations and to be covered by our databases, but are at the same time less important and sizeable than the aforementioned primary markets. In Table 1 we show that the set of secondary office cities consists of Glasgow, Barcelona, Düsseldorf, Lyon, and Rotterdam.

From the statistics of Table 1 we can clearly see that the key office markets in all five countries are considerably larger than their second tier counterparts. ${ }^{7}$ The smallest geographic area for which economic data are available in Spain is based on provincias and is considerably larger than Nuts 3 regions in other countries. The economic center of each provincia is, however, the city on which we base our analysis. We find the highest density of office space per capita in the five primary office markets.

The dependent variable in this study is changes in real prime rents. Prime rents are for the better quality central office space and as such do not always reflect changes for the overall office market although Class A offices make up a large share of office space in major cities. In line with Hendershott et al. (1999) we use the GDP deflator to transform nominal changes into real prime rent changes. Figure 1 presents the history of our dependent variable over the study period for the premier tier cities.

The prime office markets in Europe underwent a full cycle over the period 19912006 with overall a reduction in rent decreases over the period 1992-1996, increasing rents over the period 1996-2001 and decreasing rents in the period 2002-

\footnotetext{
${ }^{7}$ Due to differences in definitions for local markets between Nuts 3 areas, which are defined by national authorities and office markets, as determined by Jones Lang LaSalle, it is not feasible to compare local office market densities.
} 
Table 1 Office market statistics

\begin{tabular}{|c|c|c|c|c|c|c|c|}
\hline Country & Population & $\begin{array}{l}\text { Land } \\
\text { area }\end{array}$ & City & Nuts 3 name & Population & $\begin{array}{l}\text { Land } \\
\text { area }\end{array}$ & $\begin{array}{l}\text { Office } \\
\text { space }\end{array}$ \\
\hline \multirow[t]{2}{*}{ United Kingdom } & \multirow[t]{2}{*}{60,284} & \multirow[t]{2}{*}{243,820} & London & Inner London & 3,001 & 321 & 19,333 \\
\hline & & & Glasgow & Glasgow City & 569 & 175 & 1,445 \\
\hline \multirow[t]{2}{*}{ Spain } & \multirow[t]{2}{*}{43,807} & \multirow[t]{2}{*}{505,997} & Madrid & Madrid & 5,984 & 8,028 & 13,743 \\
\hline & & & Barcelona & Barcelona & 5,140 & 7,729 & 5,038 \\
\hline \multirow[t]{2}{*}{ Germany } & \multirow[t]{2}{*}{82,642} & \multirow[t]{2}{*}{357,030} & Frankfurt & $\begin{array}{l}\text { Frankfurt am Main, } \\
\text { Kreisfreie Stadt }\end{array}$ & 650 & 248 & 11,610 \\
\hline & & & Dusseldorf & $\begin{array}{l}\text { Düsseldorf, } \\
\text { Kreisfreie Stadt }\end{array}$ & 572 & 217 & 8,447 \\
\hline \multirow[t]{2}{*}{ France } & \multirow[t]{2}{*}{60,850} & \multirow[t]{2}{*}{543,965} & Paris & Paris & 2,149 & 105 & 49,125 \\
\hline & & & Lyon & Rhone & 1,656 & 3,249 & 4,314 \\
\hline \multirow[t]{2}{*}{ The Netherlands } & \multirow[t]{2}{*}{16,426} & \multirow[t]{2}{*}{33,938} & Amsterdam & Groot-Amsterdam & 1,214 & 732 & 6,987 \\
\hline & & & Rotterdam & Groot-Rijnmond & 1,368 & 1,188 & 3,685 \\
\hline
\end{tabular}

This table shows statistics on population and land area totals for the countries and cities included in the study in 2006. Population is measured as the number of inhabitants in '000s. Land area is in square kilometers and excludes inland waters. Nuts 3 name is the official name of the region according to EuroStat classification of geographic areas. Office space is in square meters and '000s and based on geographic areas as defined by Jones Lang LaSalle. Source: EuroStat and Jones Lang LaSalle

2004 with mixed positive changes during the last years. Table 2 presents summary statistics of variables shown in Fig. 1 where the values in parentheses indicate the year in which the respective minimum or maximum prime rent change was achieved. Table 2 shows that the heydays of European office markets took place around the Dotcom boom of the years preceding the change of the millennium. Amsterdam is

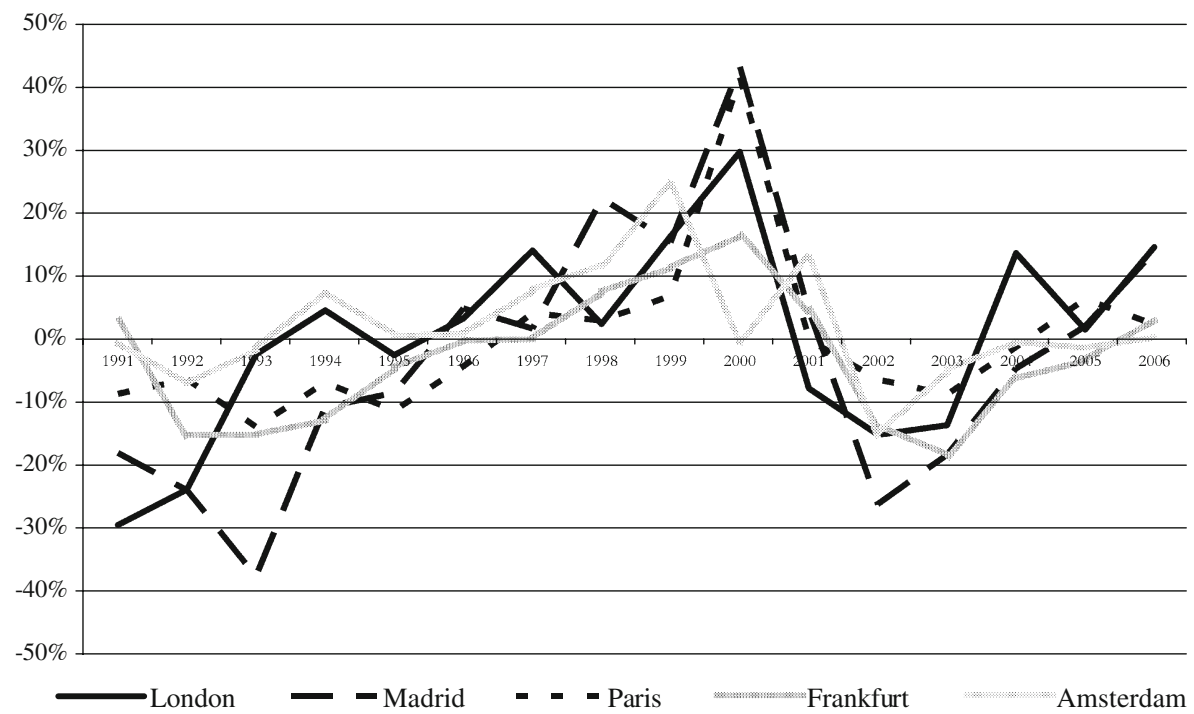

Fig. 1 Changes in real prime office rents (premier tier cities). This figure shows annual percentage changes in real prime rent levels for the largest office markets per country included in the study over the period 1991-2006. Nominal rents are converted to real rents with the GDP deflator. Source: DataStream and Jones Lang LaSalle 
Table 2 Statistics of real prime rent changes premier tier cities

\begin{tabular}{llllll}
\hline & London & Madrid & Paris & Frankfurt & Amsterdam \\
\hline Min & $-35.28 \%$ & $-47.69 \%$ & $-15.38 \%$ & $-20.73 \%$ & $-16.90 \%$ \\
& $(1991)$ & $(1993)$ & $(1993)$ & $(2003)$ & $(2002)$ \\
Max & $25.77 \%$ & $35.72 \%$ & $34.47 \%$ & $14.91 \%$ & $21.66 \%$ \\
& $(2000)$ & $(2000)$ & $(2000)$ & $(2000)$ & $(1999)$ \\
Average & $-1.17 \%$ & $-4.95 \%$ & $-1.23 \%$ & $-3.60 \%$ & $1.50 \%$ \\
SD & $16.33 \%$ & $21.21 \%$ & $11.57 \%$ & $10.66 \%$ & $8.86 \%$ \\
\hline
\end{tabular}

This table shows summary statistics for changes in real prime rents for the largest office markets per country in our sample. The largest negative change is indicated with Min and the largest positive change is indicated with Max. The numbers in parentheses shows the year in which the Min and Max per office market occurred. Average indicates the mean change in real prime rent over the sample period and St. Dev. shows the annual standard deviation of changes in real prime rents. Source: DataStream and Jones Lang LaSalle

the only market with positive average real rent changes and Madrid is the city that combines the largest average drop with the highest volatility although much of the decrease was established during the first 3 years of the sample.

The second tier office markets shown in Fig. 2 and Table 3 display a pattern comparable to the larger cities but with less volatility. Again it is the Spanish city that exhibits the largest average drop in real rents; a direct resultant of changes during the first 5 years covered and high inflation. Although contemporaneous correlations indicate low similarities between markets, Figs. 1 and 2 indicate a pattern of rent changes that shows peaks and troughs of prime rent changes within 2 years across cities following developments in the broader economy.

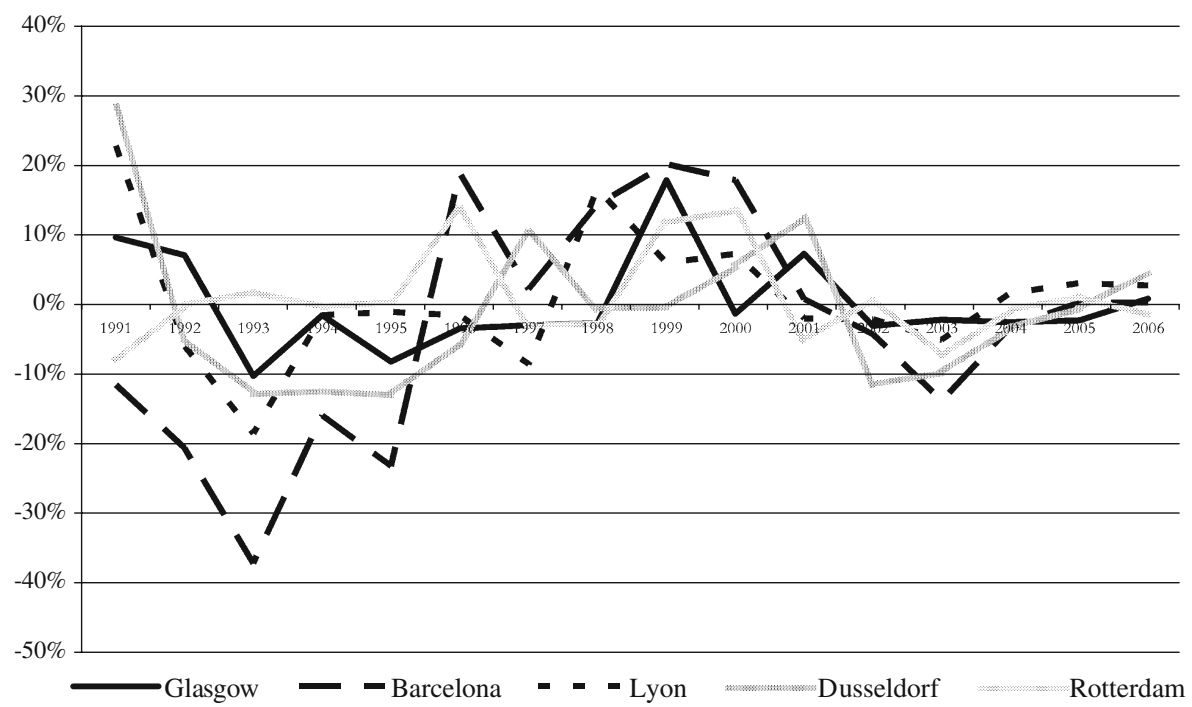

Fig. 2 Changes in real prime office rents (second tier cities). This figure shows annual percentage changes in real prime rent levels for the second largest office markets per country included in the study over the period 1991-2006. Nominal rents are converted to real rents with the GDP deflator. Source: DataStream and Jones Lang LaSalle 
Table 3 Statistics of real prime rent changes second tier cities

\begin{tabular}{llllll}
\hline & Glasgow & Barcelona & Lyon & Düsseldorf & Rotterdam \\
\hline Min & $-10.75 \%$ & $-46.25 \%$ & $-20.36 \%$ & $-13.88 \%$ & $-8.54 \%$ \\
& $(1993)$ & $(1993)$ & $(1993)$ & $(1995)$ & $(1991)$ \\
Max & $16.40 \%$ & $18.33 \%$ & $20.47 \%$ & $24.97 \%$ & $12.73 \%$ \\
& $(1999)$ & $(1999)$ & $(1991)$ & $(1991)$ & $(2000)$ \\
Average & $-0.07 \%$ & $-4.91 \%$ & $0.44 \%$ & $-1.41 \%$ & $0.66 \%$ \\
SD & $6.81 \%$ & $17.81 \%$ & $9.40 \%$ & $10.80 \%$ & $6.44 \%$ \\
\hline
\end{tabular}

This table shows summary statistics changes in real prime rents for the second largest office market per country in our sample. The largest negative change is indicated with Min and the largest positive change is indicated with Max. The numbers in parentheses shows the year in which the Min and Max per office market occurred. Average indicates the mean change in real prime rent over the sample period and St. Dev. shows the annual standard deviation of changes in real prime rents. Source: DataStream and Jones Lang LaSalle

The weight of full time equivalent employment in office occupying services industries as a percentage of total employment is on average $72 \%$ on a national level whereas the premier and second tier office cities shows weights of $87 \%$ and $78 \%$ respectively. The weight of GDP in the national aggregate is on average $11 \%$ for the premier cities and $6 \%$ for the secondary office markets while their weight in total population is $6 \%$ and $5 \%$ respectively. This clearly illustrates the dominant position the premier office cities take within their respective national economies. The premier tier cities included in our study, being the financial hearts of the countries, house a large number of (inter)national headquarters which makes them mostly vulnerable to economic shocks on the macro level. Second tier cities with more local based companies are expected to exhibit more relation with local economic changes.

Table 4 displays values of dependent and independent variables included in our analysis for the years 1991 and 2006 and some summary statistics over the sample period.

Table 4 Summary statistics economic variables

\begin{tabular}{|c|c|c|c|c|c|c|c|}
\hline & $\begin{array}{l}\text { Real } \\
\text { prime } \\
\text { rent }\end{array}$ & $\begin{array}{l}\text { Office } \\
\text { stock }\end{array}$ & $\begin{array}{l}\text { Vacancy } \\
\text { rate }(\%)\end{array}$ & $\begin{array}{l}\text { Serv. Industry } \\
\text { FTE national }\end{array}$ & $\begin{array}{l}\text { Serv.Industry } \\
\text { FTE local }\end{array}$ & $\begin{array}{l}\text { Real GDP } \\
\text { national }\end{array}$ & $\begin{array}{l}\text { Real GDP } \\
\text { local }\end{array}$ \\
\hline \multicolumn{8}{|l|}{ Paris } \\
\hline 1991 & 625 & 37,658 & 4 & 14,192 & 1,457 & $1,170,254$ & 128,280 \\
\hline 2006 & 564 & 49,125 & 5 & 16,802 & 1,448 & $1,232,447$ & 120,394 \\
\hline Average & 525 & 43,279 & 6 & 15,273 & 1,426 & $1,198,672$ & 124,085 \\
\hline$\Delta^{\mathrm{a}}(\%)$ & -1.2 & 2.0 & 2.2 & 1.1 & -0.1 & 0.3 & -0.6 \\
\hline $\mathrm{SD} \Delta(\%)$ & 11.6 & 1.4 & 1.4 & 1.0 & 1.8 & 1.7 & 2.3 \\
\hline \multicolumn{8}{|l|}{ Frankfurt } \\
\hline 1991 & 535 & 7,500 & 2 & 20,326 & 402 & $1,628,371$ & 35,048 \\
\hline 2006 & 293 & 11,610 & 17 & 23,229 & 452 & $1,657,370$ & 35,047 \\
\hline Average & 373 & 9,497 & 8 & 21,960 & 422 & $1,593,047$ & 34,387 \\
\hline$\Delta^{\mathrm{a}}(\%)$ & -3.6 & 2.7 & 13.6 & 0.9 & 0.8 & 0.1 & 0.0 \\
\hline $\mathrm{SD} \Delta(\%)$ & 10.7 & 1.9 & 48.6 & 0.8 & 1.8 & 2.0 & 3.0 \\
\hline
\end{tabular}


Table 4 (continued)

\begin{tabular}{|c|c|c|c|c|c|c|c|}
\hline & $\begin{array}{l}\text { Real } \\
\text { prime } \\
\text { rent }\end{array}$ & $\begin{array}{l}\text { Office } \\
\text { stock }\end{array}$ & $\begin{array}{l}\text { Vacancy } \\
\text { rate }(\%)\end{array}$ & $\begin{array}{l}\text { Serv. Industry } \\
\text { FTE national }\end{array}$ & $\begin{array}{l}\text { Serv.Industry } \\
\text { FTE local }\end{array}$ & $\begin{array}{l}\text { Real GDP } \\
\text { national }\end{array}$ & $\begin{array}{l}\text { Real GDP } \\
\text { local }\end{array}$ \\
\hline \multicolumn{8}{|l|}{ London } \\
\hline 1991 & 492 & 17,402 & 14 & 15,877 & 1,704 & $1,022,519$ & 113,533 \\
\hline 2006 & 580 & 19,333 & 6 & 19,684 & 2,114 & $1,031,684$ & 119,672 \\
\hline Average & 486 & 18,085 & 9 & 17,451 & 1,892 & $1,025,067$ & 116,815 \\
\hline$\Delta^{\mathrm{a}}(\%)$ & -1.2 & 1.0 & -2.5 & 1.3 & 1.0 & -0.5 & -0.4 \\
\hline $\mathrm{SD} \Delta(\%)$ & 16.3 & 1.6 & 34.2 & 1.2 & 2.8 & 2.6 & 4.1 \\
\hline \multicolumn{8}{|l|}{ Madrid } \\
\hline 1991 & 339 & 9,574 & 4 & 8,823 & 1,679 & 577,603 & 99,761 \\
\hline 2006 & 188 & 13,743 & 5 & 12,315 & 2,382 & 497,953 & 88,391 \\
\hline Average & 208 & 11,461 & 6 & 9,946 & 1,904 & 519,421 & 91,002 \\
\hline$\Delta^{\mathrm{a}}(\%)$ & -4.9 & 2.4 & 1.3 & 2.3 & 2.4 & -1.2 & -1.1 \\
\hline $\mathrm{SD} \Delta(\%)$ & 21.2 & 1.7 & 48.7 & 1.5 & 1.6 & 2.5 & 2.6 \\
\hline \multicolumn{8}{|l|}{ Amsterdam } \\
\hline 1991 & 198 & 5,053 & 6 & 3,713 & 476 & 320,548 & 34,158 \\
\hline 2006 & 254 & 6,987 & 17 & 4,479 & 552 & 359,661 & 41,254 \\
\hline Average & 235 & 5,856 & 8 & 4,197 & 519 & 347,412 & 37,963 \\
\hline$\Delta^{\mathrm{a}}(\%)$ & 1.5 & 2.5 & 6.3 & 1.3 & 1.1 & 0.7 & $1.2 \%$ \\
\hline $\mathrm{SD} \Delta(\%)$ & 8.9 & 1.9 & 34.8 & 1.6 & 2.7 & 4.2 & 4.3 \\
\hline \multicolumn{8}{|l|}{ Lyon } \\
\hline 1991 & 187 & 3,250 & 8 & 14,192 & 451 & $1,170,254$ & 38,106 \\
\hline 2006 & 164 & 4,314 & 6 & 16,802 & 528 & $1,232,447$ & 42,753 \\
\hline Average & 155 & 3,773 & 6 & 15,273 & 480 & $1,198,672$ & 40,027 \\
\hline$\Delta^{\mathrm{a}}(\%)$ & 0.4 & 2.3 & 2.7 & 1.1 & 0.9 & 0.3 & 0.6 \\
\hline $\mathrm{SD} \Delta(\%)$ & 9.4 & 2.8 & 26.9 & 1.0 & 1.5 & 1.7 & 2.2 \\
\hline \multicolumn{8}{|l|}{ Dusseldorf } \\
\hline 1991 & 315 & 4,690 & 1 & 20,326 & 299 & $1,628,371$ & 27,658 \\
\hline 2006 & 196 & 8,447 & 12 & 23,229 & 330 & $1,657,370$ & 27,741 \\
\hline Average & 223 & 6,640 & 6 & 21,960 & 315 & $1,593,047$ & 27,012 \\
\hline$\Delta^{\mathrm{a}}(\%)$ & -1.4 & 4.1 & 16.3 & 0.9 & 0.7 & 0.1 & 0.0 \\
\hline $\mathrm{SD} \Delta(\%)$ & 10.8 & 4.8 & 31.6 & 0.8 & 1.5 & 2.0 & 2.3 \\
\hline \multicolumn{8}{|l|}{ Glasgow } \\
\hline 1991 & 183 & 1,455 & 11 & 15,877 & 243 & $1,022,519$ & 14,438 \\
\hline 2006 & 165 & 1,445 & 6 & 19,684 & 302 & $1,031,684$ & 13,776 \\
\hline Average & 168 & 1,446 & 8 & 17,451 & 266 & $1,025,067$ & 13,813 \\
\hline$\Delta^{\mathrm{a}}(\%)$ & -0.1 & 0.0 & -0.1 & 1.3 & 1.4 & -0.5 & -0.9 \\
\hline $\mathrm{SD} \Delta(\%)$ & 6.8 & 6.8 & 28.0 & 1.2 & 2.2 & 2.6 & 3.1 \\
\hline \multicolumn{8}{|l|}{ Barcelona } \\
\hline 1991 & 287 & 3,520 & 5 & 8,823 & 1,118 & 577,603 & 82,826 \\
\hline 2006 & 148 & 5,038 & 5 & 12,315 & 1,604 & 497,953 & 69,542 \\
\hline Average & 167 & 4,328 & 6 & 9,946 & 1,285 & 519,421 & 74,452 \\
\hline$\Delta^{\mathrm{a}}(\%)$ & -4.9 & 2.4 & -0.1 & 2.3 & 2.5 & -1.2 & -1.3 \\
\hline $\mathrm{SD} \Delta(\%)$ & 17.8 & 1.5 & 37.6 & 1.5 & 1.5 & 2.5 & 2.3 \\
\hline \multicolumn{8}{|l|}{ Rotterdam } \\
\hline 1991 & 121 & 2,915 & 9 & 3,713 & 348 & 320,548 & 29,082 \\
\hline 2006 & 146 & 3,685 & 8 & 4,479 & 410 & 359,661 & 30,672 \\
\hline
\end{tabular}


Table 4 (continued)

\begin{tabular}{lrrrrrrr}
\hline & $\begin{array}{l}\text { Real } \\
\text { prime } \\
\text { rent }\end{array}$ & $\begin{array}{l}\text { Office } \\
\text { stock }\end{array}$ & $\begin{array}{l}\text { Vacancy } \\
\text { rate }(\%)\end{array}$ & $\begin{array}{l}\text { Serv. Industry } \\
\text { FTE national }\end{array}$ & $\begin{array}{l}\text { Serv.Industry } \\
\text { FTE local }\end{array}$ & $\begin{array}{l}\text { Real GDP } \\
\text { national }\end{array}$ & $\begin{array}{l}\text { Real GDP } \\
\text { local }\end{array}$ \\
\hline Average & 139 & 3,315 & 7 & 4,197 & 386 & 347,412 & 30,116 \\
$\Delta^{\mathrm{a}}(\%)$ & 0.7 & 1.7 & 0.1 & 1.3 & 1.2 & 0.7 & 0.3 \\
$\mathrm{SD} \Delta(\%)$ & 6.4 & 1.6 & 23.0 & 1.6 & 1.9 & 4.2 & 4.2 \\
\hline
\end{tabular}

Summary statistics for the variables included in the analysis where all nominal values have been converted to real values with a GDP deflator. Real prime rent indicates the rent per square meter in Euros (expect for London and Glasgow where rent levels are in Pounds). The office stock reports the total area of office space in thousands of square meters within the local office market as defined by Jones Lang LaSalle. Vacancy rate reflects local vacant office space as a percentage of office stock. Serv. Industry FTE national is the number of full time equivalent employees occupied in service industry within the country. Serv. Industry FTE local reflects the same information on a local (Nuts 3) level. Real GDP national is the national gross domestic product in local currencies (*mln). Real GDP local shows the same information on a local level. 1991 indicates the level of variables in the year 1991. 2006 indicates the level of variables in the year 2006. SD $\Delta$ shows the standard deviation of annual changes over the period 1991-2006. Source: Agora Data, EuroStat and Jones Lang LaSalle

${ }^{a}$ Average indicates the average level of the variable over the period 1991-2006. Average $\Delta$ shows the average annual change over the period 1991-2006

The database shows that large cities are generally more volatile than their smaller counterparts on a country by country basis. Changes in real prime rents and vacancy rates are nine out of ten times more volatile in the largest city of the country. For the economic variables changes in service sector employment and real GDP we observe the larger cities are for each pair more volatile than their smaller counterparts although differences can be small. We show that over the sample period real GDP (constant 2002 PPS) increased in four out of five countries while the same holds for only half of the cities. Like the office stock, service sector employment grew in nine out of ten cities between 1991 and 2006.

An overview of the correlations of the variables used in this paper is provided in Table 5 and shows that correlations, for all cities within the tier, and years combined, between national and local economic variables are high and statistically significant at the $1 \%$ level.

One of the most striking results in Table 5 is the high correlation between national and local economic figures for both tiers of cities included in our analysis. A possible explanation for this finding is that the cities included in our sample constitute a large weight in the national aggregates and are therefore naturally linked to the aggregate figure. Despite the inclusion of second tier cities, with by definition smaller economies than the premier cities, we do not find that these cities are less correlated with the national aggregate. Furthermore, the most detailed regional data available for Europe are on a Nuts 3 level which, for some cities, can still include a large area of land and large number of inhabitants. This sometimes limited level of detail naturally limits discrepancies between national and local data. While the correlation between changes in real prime rent and dependent variables is strong and significant for the premier tier cities this is far less present in Panel B. Further 
Table 5 Cross-correlations among real estate and economic variables

\begin{tabular}{|c|c|c|c|c|c|c|c|}
\hline & (1) & (2) & (3) & (4) & (5) & (6) & (7) \\
\hline \multicolumn{8}{|l|}{ Panel A } \\
\hline$\Delta$ Real prime rent $(1)$ & 1.00 & $-0.43 * *$ & $-0.60 * *$ & $0.53 * *$ & $0.51 * *$ & $0.68 * *$ & $0.70 * *$ \\
\hline$\Delta$ Total stock (2) & $-0.43 * *$ & 1.00 & $0.52 * *$ & $-0.28^{*}$ & $-0.23^{*}$ & $-0.35^{* *}$ & $-0.36 * *$ \\
\hline$\Delta$ Vacancy rate $(3)$ & $-0.60 * *$ & $0.52 * *$ & 1.00 & $-0.38 * *$ & $-0.34 * *$ & $-0.41 * *$ & $-0.44 * *$ \\
\hline $\begin{array}{l}\Delta \text { Service sector employment } \\
\text { (national) (4) }\end{array}$ & $0.53 * *$ & $-0.28 *$ & $-0.38 * *$ & 1.00 & $0.79 * *$ & $-0.41 * *$ & $0.45^{* *}$ \\
\hline $\begin{array}{l}\Delta \text { Service sector employment } \\
\text { (local) }(5)\end{array}$ & $0.51 * *$ & $-0.23^{*}$ & $-0.34 * *$ & $0.79 * *$ & 1.00 & $0.37 * *$ & $0.53 * *$ \\
\hline$\Delta$ Real GDP (national) (6) & $0.68 * *$ & $-0.35 * *$ & $-0.41 * *$ & $0.41 * *$ & $0.37 * *$ & 1.00 & $0.90 * *$ \\
\hline$\Delta$ Real GDP (local) (7) & $0.70 * *$ & $-0.36 * *$ & $-0.44 * *$ & $0.45 * *$ & $0.53 * *$ & $0.90 * *$ & 1.00 \\
\hline \multicolumn{8}{|l|}{ Panel B } \\
\hline$\Delta$ Real prime rent $(1)$ & 1.00 & -0.05 & -0.22 & $0.37 * *$ & 0.25 & $0.41 * *$ & $0.38 * *$ \\
\hline$\Delta$ Total stock (2) & -0.05 & 1.00 & 0.19 & -0.13 & $-0.27^{*}$ & -0.07 & -0.08 \\
\hline$\Delta$ Vacancy rate $(3)$ & -0.22 & 0.19 & 1.00 & $-0.37 * *$ & $-0.25^{*}$ & $-0.43 * *$ & $-0.45 * *$ \\
\hline $\begin{array}{l}\Delta \text { Service sector employment } \\
\text { (national) (4) }\end{array}$ & $0.37 * *$ & -0.13 & $-0.37 * *$ & 1.00 & $0.76^{* *}$ & $0.46^{* *}$ & $0.41 * *$ \\
\hline $\begin{array}{l}\Delta \text { Service sector employment } \\
\text { (local) }(5)\end{array}$ & 0.25 & -0.27 & $-0.25^{*}$ & $0.76^{* *}$ & 1.00 & 0.20 & $0.28 *$ \\
\hline$\Delta$ Real GDP (national) (6) & $0.41 * *$ & -0.07 & $-0.43 * *$ & $0.46^{* *}$ & 0.20 & 1.00 & $0.93 * *$ \\
\hline$\Delta$ Real GDP (local) $(7)$ & $0.38 * *$ & -0.08 & $-0.45 * *$ & $0.41 * *$ & $0.28 *$ & $0.93 * *$ & 1.00 \\
\hline
\end{tabular}

Correlations between changes in real prime rents [indicated as (1)] and real estate supply and demand [(2) and (3)] variables and indicators of economic growth traditionally related to changes on office markets on a national [(4) and (6)]; and on a local [(5) and (7)] level. Panel A shows figures for the premier tier cities; Panel B for the second tier cities

${ }^{*} p=0.05,{ }^{* *} p=0.01$ level (2-tailed); source: Agora Data, EuroStat and Jones Lang LaSalle

analysis on a city level reveals that this result is not based on outliers but consistent for the majority of cities within the tier.

\section{Regression Results}

In this section we present the results for the two stage error correction model for changes in prime office rents. Given our a priori hypothesis that second tier cities gain most by modeling office rents on local data we present the analysis in two separate sections; Table 6 displays the results for the large cities and Table 7 for the second tier cities. The top panels of both tables display the results for the long run model based on level data which is used to calculate the difference between the existing rent level and the rent level that is expected based on long run relations between dependent and independent variables. The estimation process is performed twice based on two levels of geographic aggregation. The first two columns show the results for economic data on an aggregate national level and the last two columns for data on a local, Nuts 3, level. We further differentiate for the type of economic data included in the analysis; Model 1 in columns one and three show the results when we use employment in service industries on a full time equivalent basis as the measure for economic activity and Model 2 in columns two and four display results for a real GDP based analysis. 
Table 6 ECM results for premier tier office markets

\begin{tabular}{|c|c|c|c|c|}
\hline & \multicolumn{2}{|l|}{ National } & \multicolumn{2}{|l|}{ Local } \\
\hline & Model 1 & Model 2 & Model 1 & Model 2 \\
\hline \multicolumn{5}{|l|}{ Long-run model } \\
\hline Constant & $\begin{array}{c}-5.337 * * \\
(2.401)\end{array}$ & $\begin{array}{r}-36.162^{*} \\
(6.041)\end{array}$ & $\begin{array}{c}-1.839 \\
(2.202)\end{array}$ & $\begin{array}{c}22.974 * \\
(3.264)\end{array}$ \\
\hline $\ln$ (FTE service industry) & $\begin{array}{c}1.529 * \\
(0.576)\end{array}$ & & $\begin{array}{c}1.448 * \\
(0.419)\end{array}$ & \\
\hline $\ln (\mathrm{GDP})$ & & $\begin{array}{c}3.061^{*} \\
(0.530)\end{array}$ & & $\begin{array}{c}2.538^{*} \\
(0.350)\end{array}$ \\
\hline $\ln [(1$-Fitted vacancy rate $) \times($ office stock $)]$ & $\begin{array}{c}-0.344 \\
(0.536)\end{array}$ & $\begin{array}{c}0.030 \\
(0.257)\end{array}$ & $\begin{array}{c}-0.257 \\
(0.414)\end{array}$ & $\begin{array}{c}0.045 \\
(0.223)\end{array}$ \\
\hline$N$ & 75 & 75 & 75 & 75 \\
\hline$R^{2}$-adj & 0.847 & 0.887 & 0.856 & 0.905 \\
\hline DW & 0.612 & 0.584 & 0.622 & 0.679 \\
\hline \multicolumn{5}{|l|}{ Short-run model } \\
\hline Constant & $\begin{array}{c}-0.021 \\
(0.019)\end{array}$ & $\begin{array}{c}0.000 \\
(0.012)\end{array}$ & $\begin{array}{c}-0.005 \\
(0.015)\end{array}$ & $\begin{array}{c}0.000 \\
(0.013)\end{array}$ \\
\hline$\Delta \ln ($ FTE service industry) & $\begin{array}{l}2.301 * * \\
(0.948)\end{array}$ & & $\begin{array}{l}1.316^{* *} \\
(0.602)\end{array}$ & \\
\hline$\Delta \ln (\mathrm{GDP})$ & & $\begin{array}{c}1.924 * \\
(0.383)\end{array}$ & & $\begin{array}{c}2.184 * \\
(0.455)\end{array}$ \\
\hline$\Delta \ln [(1$-Fitted vacancy rate $) \times($ office stock $)]$ & $\begin{array}{c}-0.192 \\
(0.400)\end{array}$ & $\begin{array}{c}-0.025 \\
(0.391)\end{array}$ & $\begin{array}{c}-0.147 \\
(0.421)\end{array}$ & $\begin{array}{c}0.048 \\
(0.395)\end{array}$ \\
\hline Error correction $\operatorname{Term}_{(t-1)}$ & $\begin{array}{c}-0.429 * \\
(0.070)\end{array}$ & $\begin{array}{c}-0.444 * \\
(0.084)\end{array}$ & $\begin{array}{c}-0.464 * \\
(0.072)\end{array}$ & $\begin{array}{c}-0.390 * \\
(0.079)\end{array}$ \\
\hline$\Delta \ln (R)_{(t-1)}$ & $\begin{array}{c}0.455^{*} \\
(0.089)\end{array}$ & $\begin{array}{c}0.360 * \\
(0.083)\end{array}$ & $\begin{array}{c}0.462 * \\
(0.093)\end{array}$ & $\begin{array}{c}0.372 * \\
(0.085)\end{array}$ \\
\hline$N$ & 70 & 70 & 70 & 70 \\
\hline$R^{2}$-adj & 0.574 & 0.589 & 0.543 & 0.572 \\
\hline DW & 2.161 & 2.083 & 2.192 & 2.050 \\
\hline
\end{tabular}

This table reports the error correction model of office rents for the five largest office markets per country included in our database. The long-run model tests $\ln R_{t}=\alpha_{0}+\alpha_{1} \ln E A_{t}+\alpha_{2} \ln \left[(1-\hat{v}) * O S_{t}\right]$ and is measured as a cross sectional fixed effect model. The dependent variable is real prime rent. Economic activity (EA) is measured with two different specifications. Model 1 shows the results of the test when EA is measured as FTE employment in the service industry. Model 2 shows results for EA measured as GDP. $\hat{v}$ is the fitted vacancy rate as determined with an $\operatorname{AR}(2)$ model. The short-run model tests $\Delta \ln R_{t}=$ $\alpha_{0}+\alpha_{1} \Delta \ln E A_{t}+\alpha_{2} \Delta \ln \left[(1-\hat{v}) * O S_{t}\right]+\alpha_{4 u_{t-1}}+\alpha_{5} \Delta \ln R_{t-1}$ and is measured as a cross sectional random effect model. $\Delta$ measures the one period change in variables. The long-run and short-run models are estimated on two levels of geographic aggregation indicated as "National" and "Local". Choice of geographic aggregation influences the measure of EA being either on a national or local level. Standard error statistics appear in parentheses

$D W$ Durbin-Watson statistic, $O S$ stock of office floor space in square meters, $\Delta \ln R_{t-1}$ one period lagged change in real prime rents, $u_{t-1}$ one period lagged residual of the long-run model and used as the error correction term in the short run model

$* p=0.10, * * p=0.05, * * * p=0.01$

Results show that the long run model has an adjusted $R^{2}$ of approximately 0.85 for all specifications of the model and Durbin Watson coefficients considerably below unity. These results are comparable to the findings of Hendershott et al. (2002b) and are a direct resultant of the trending variables used in the long-run model. From the top panel of Table 6 we derive that the implied price and income 
Table 7 ECM results for second tier office markets

\begin{tabular}{|c|c|c|c|c|}
\hline & \multicolumn{2}{|l|}{ National } & \multicolumn{2}{|l|}{ Local } \\
\hline & Model 1 & Model 2 & Model 1 & Model 2 \\
\hline \multicolumn{5}{|l|}{ Long-run model } \\
\hline Constant & $\begin{array}{c}-1.261 \\
(1.606)\end{array}$ & $\begin{array}{r}-16.249^{*} \\
(4.854)\end{array}$ & $\begin{array}{l}2.232^{* *} \\
(1.163)\end{array}$ & $\begin{array}{c}-5.492 \\
(3.305)\end{array}$ \\
\hline $\ln$ (FTE service industry) & $\begin{array}{c}1.118 * \\
(0.248)\end{array}$ & & $\begin{array}{l}0.961 * * \\
(0.220)\end{array}$ & \\
\hline $\ln (\mathrm{GDP})$ & & $\begin{array}{c}1.739 * \\
(0.404)\end{array}$ & & $\begin{array}{c}1.099 * \\
(0.354)\end{array}$ \\
\hline $\ln [(1-$ Fitted vacancy rate $) \times($ office stock $)]$ & $\begin{array}{c}-0.515^{*} \\
(0.192)\end{array}$ & $\begin{array}{c}-0.288^{* * *} \\
(0.163)\end{array}$ & $\begin{array}{c}-0.374 * * \\
(0.174)\end{array}$ & $\begin{array}{c}-0.100 \\
(0.157)\end{array}$ \\
\hline$N$ & 74 & 74 & 74 & 74 \\
\hline$R^{2}$-adj & 0.686 & 0.679 & 0.681 & 0.642 \\
\hline DW & 0.664 & 0.552 & 0.657 & 0.488 \\
\hline \multicolumn{5}{|l|}{ Short-run model } \\
\hline Constant & $\begin{array}{c}-0.023 \\
(0.014)\end{array}$ & $\begin{array}{c}-0.008 \\
(0.009)\end{array}$ & $\begin{array}{c}-0.016 \\
(0.012)\end{array}$ & $\begin{array}{c}-0.009 \\
(0.009)\end{array}$ \\
\hline$\Delta \ln ($ FTE service industry) & $\begin{array}{l}1.384 * * \\
(0.682)\end{array}$ & & $\begin{array}{l}0.877 * * * \\
(0.462)\end{array}$ & \\
\hline$\Delta \ln (\mathrm{GDP})$ & & $\begin{array}{c}0.835^{* *} \\
(0.339)\end{array}$ & & $\begin{array}{c}1.029 * \\
(0.339)\end{array}$ \\
\hline$\Delta \ln [(1$-fitted vacancy rate $) *($ office stock $)]$ & $\begin{array}{c}0.119 \\
(0.274)\end{array}$ & $\begin{array}{c}0.219 \\
(0.273)\end{array}$ & $\begin{array}{c}0.223 \\
(0.276)\end{array}$ & $\begin{array}{c}0.160 \\
(0.269)\end{array}$ \\
\hline Error correction $\operatorname{Term}_{(t-1)}$ & $\begin{array}{c}-0.450^{*} \\
(0.076)\end{array}$ & $\begin{array}{c}-0.356^{*} \\
(0.074)\end{array}$ & $\begin{array}{c}-0.448 * \\
(0.075)\end{array}$ & $\begin{array}{c}-0.401 * \\
(0.074)\end{array}$ \\
\hline$\Delta \ln (R)_{(t-1)}$ & $\begin{array}{c}0.314^{*} \\
(0.083)\end{array}$ & $\begin{array}{c}0.308 * \\
(0.078)\end{array}$ & $\begin{array}{c}0.338 * \\
(0.080)\end{array}$ & $\begin{array}{c}0.308 * \\
(0.078)\end{array}$ \\
\hline$N$ & 69 & 69 & 69 & 69 \\
\hline$R^{2}$-adj & 0.446 & 0.447 & 0.435 & 0.463 \\
\hline DW & 2.501 & 2.588 & 2.526 & 2.585 \\
\hline
\end{tabular}

Error correction model of office rents for the five smallest office markets per country included in our database. The long-run model tests $\ln R_{t}=\alpha_{0}+\alpha_{1} \ln E A_{t}+\alpha_{2} \ln \left[(1-\hat{v}) * O S_{t}\right]$ and is measured as a cross sectional fixed effect model. The dependent variable is real prime rent. Economic activity is measured with two different specifications. Model 1 shows the results of the test when EA is measured as FTE employment in the service industry. Model 2 shows results for EA measured as GDP. The short-run model tests $\Delta \ln R_{t}=\alpha_{0}+\alpha_{1} \Delta \ln E A_{t}+\alpha_{2} \Delta \ln \left[(1-\hat{v}) * O S_{t}\right]+\alpha_{4 u_{t-1}}+\alpha_{5} \Delta \ln R_{t-1}$ and is measured as a cross sectional random effect model. $\Delta$ measures the one period change in variables. $u_{t-1}$ is the one period lagged residual of the long-run model and used as the error correction term in the short run model. The long-run and short-run models are estimated on two levels of geographic aggregation indicated as "National" and "Local". Choice of geographic aggregation influences the measure of EA being either on a national or local level. Standard error statistics appear in parentheses

$E A$ Economic activity, $\hat{v}$ fitted vacancy rate as determined with an AR(2) model, OS stock of office floor space in square meters, $\Delta \ln R_{t-1}$ one period lagged change in real prime rents, $D W$ Durbin-Watson statistic $* p=0.10, * * p=0.05, * * * p=0.01$

elasticity, $\lambda_{1}$ and $\lambda_{2}$ of Eq. 5, as $1 / \gamma 2$ and $-\gamma 1 / \gamma 2$ for the model based on national data are -2.91 and 4.44 , respectively, for the model including service industry employment as the economic activity variable ${ }^{8}$. Hence, if rents increase with $10 \%$

\footnotetext{
${ }^{8}$ Elasticities for the model based on local economic data are comparable in sign and magnitude. Unfortunately the coefficient for the supply and vacancy variables as included in our long term model are highly insignificant which casts doubts on the usability of elasticity measures.
} 
we expect that demand declines with $29.1 \%$, and by the same token if employment in service industry would rise with $10 \%$ we expect demand for office supply to increase with $44.4 \%$.

When distinguishing between national aggregates and local economic data, Table 6 shows that for the long-run model we find somewhat stronger results when economic activity is determined on Nuts 3-level, however, differences are marginal at best. From this long-run model as depicted in the top panel of Table 6, only the residual is used in the corresponding short-term rent adjustment model. With the stationarity of residuals assured we can include the residual as an explanatory variable in the short-run rent adjustment model ${ }^{9}$. The regression results for this short-run model are presented in the bottom panel of Table 6. In model 1, in which service employment is the proxy for economic activity, we find the employment, and error correction coefficients are correctly signed. In the short-run office rents tend to increase with service employment. Furthermore, we find that office rents partially adjust to the lagged market imbalance, measured as the deviation of rent from its long-run value ${ }^{10}$. We find GDP to be the most powerful proxy for economic activity, although differences in results are marginal. Again, we also find that when switching to local economic variables, our results hardly differ from the findings based on national aggregates.

In the final step of our analysis we repeat the complete analysis for the set of secondary office markets. In Table 7 we present the results for this exercise. Again the long-run model is presented in the top panel, with the short-run model depicted below.

For the long-run model we find less explanatory power for these secondary markets, compared to the previous results for the largest markets. Contrary to the results presented in Table 6 we now find significant coefficients for the office stock variable, which results in more plausible elasticities of -1.94 and 6.04 for price and income. Again, we tested the residuals from this long-run model for stationarity and unit roots and subsequently included the residual term into the short-run model that is presented in the second portion of Table 7 . In contrast with our expectations we find no clear evidence that local model specifications work better for explaining the rent dynamics of secondary office markets. Comparing results of lower panel of Table 7 leads to mixed conclusions. When considering service employment, national data appear to perform best, while the opposite is true for GDP. Moreover, in line with our results in Table 6 we again find the expected negative signs the error correction term and significantly positive relations the lagged rent changes. The economic activity measures have a consistent and positive impact on office rents, while the combined vacancy rates and office stock variable does not appear to have any significant influence on the short-run behavior of European office rents.

\footnotetext{
${ }^{9}$ Levin et al. (2002) unit root tests for panel data indicate that residuals from the long-run model are stationary.

${ }^{10}$ Given that the error correction coefficient takes values between -0.390 and -0.464 we must conclude that there is partial adjustment to the long-run equilibrium.
} 


\section{Conclusion and Discussion}

Understanding the dynamics of local office markets is key for investors, tenants and local governments. This study provides new insights in the dynamics of European office markets by capturing long-run equilibrium relationships of demand and supply variables and their short-term corrections. The prime distinctive feature of this study is the use of economic variables on two separate levels of geographic aggregation; i.e. the national and local level. We employ a two equation error correction model on unique data provided by Jones Lang LaSalle, EuroStat and Experian for five premier and $5 \mathrm{~s}$ tier European office markets. We cover the period 1990 until 2007 and our results indicate that prime office rents are significantly influenced by short-run changes in measures of economic activity, one period lagged changes in rents and we show that prime office rents partially adjust towards long-run equilibrium levels after 1 year. We vary the definition of economic activity using service employment, and GDP but find only marginal differences in our model performance. Our results do not provide any evidence that economic variables defined at the local level perform better in a model of local office rent dynamics than their national counterparts for our sample of European office markets. A priori different results were expected given the potential shift-share problem in office market research (Hekman 1984). This problem states that national aggregates provide wrong estimates for local office markets if local variables do not move in tandem with the national aggregates due to different growth rates of the cities themselves or different growth rates of industries within the cities. Results of this study indicate that national and local changes in economic variables do to a large extent move in tandem for the cities included in our analysis, leading to indistinguishable results between models based on local or national specified data. This result is to a large extent a resultant of the contribution the office markets included in our analysis have in the national aggregates of economic activity. On average we find that the comovement between national aggregates and local economic developments is much lower for smaller sized cities for which no rent data are available.

Acknowledgements We thank Jones Lang LaSalle, Experian and Agora Data for data support. Furthermore we thank participants in the ARES Annual Meeting 2007 in San Francisco and participants in the ERES Annual Meeting 2007 in London for helpful comments. In particular we thank Pat Hendershott, Bryan MacGregor, an anonymous referee and the editor, C. F. Sirmans for valuable comments on earlier versions of this paper. Any remaining errors remain ours.

Open Access This article is distributed under the terms of the Creative Commons Attribution Noncommercial License which permits any noncommercial use, distribution, and reproduction in any medium, provided the original author(s) and source are credited.

\section{References}

Blank, D. M., \& Winnick, L. (1953). The structure of the housing market. Quarterly Journal of Economics, 67, 181-203.

Ciccone, A. (2002). Agglomeration effects in Europe. European Economic Review, 46, $213-227$.

D’Arcy, E., McGough, T., \& Tsolacos, S. (1997). National economic trends, market size and city growth effects on European office rents. Journal of Property Research, 14(4), 297-308. 
D’Arcy, E., McGough, T., \& Tsolacos, S. (1999). An econometric analysis and forecasts of the office rental cycle in the Dublin area. Journal of Property Research, 16(4), 309-321.

De Wit, I., \& van Dijk, R. (2003). The global determinants of direct office real estate returns. Journal of Real Estate Finance and Economics, 26(1), 27-45.

Giussani, B., Hsia, M., \& Tsolacos, S. (1992). A comparative analysis of the major determinants of office rental values in Europe. Journal of Property Valuation and Investment, 11, 157-173.

Gordon, J., Mosbaugh, P., \& Canter, T. (1996). Integrating regional economic indicators with the real estate cycle. The Journal of Real Estate Research, 12(3), 469-501.

Grenadier, S. R. (1995). Local and national determinants of office vacancies. Journal of Urban Economics, 37, 57-71.

Hanink, D. M. (1996). How "Local" are local office markets. Real Estate Economics, 24(3), 341-358.

Hekman, J. (1984). Rental price adjustments and investment in the office market. AREUEA Journal, 13 (1), 31-47.

Hendershott, P. H. (1996). Rental adjustment and valuation in overbuilt markets: evidence from the Sydney office market. Journal of Urban Economics, 39, 51-67.

Hendershott, P. H., Lizieri, C. M., \& Matysiak, G. A. (1999). The workings of the London office market. Real Estate Economics, 27(2), 365-387.

Hendershott, P. H., MacGregor, B., \& Tse, R. (2002a). Estimation of the rental adjustment process. Real Estate Economics, 30(2), 165-183.

Hendershott, P. H., MacGregor, B., \& White, M. (2002b). Explaining real commercial rents using an error correction model with panel data. Journal of Real Estate Finance and Economics, 24(1/2), 59-87.

Levin, A., Lin, C. F., \& Chu, S. S. (2002). Unit root tests in panel data: asymptotic and finite sample properties. Journal of Econometrics, 108, 1-24.

McDonald, J. F. (2000). Rent, vacancy and equilibrium in real estate markets. Journal of Real Estate Practice and Education, 3(1), 55-69.

McDonald, J. F. (2002). A survey of econometric models of office markets. Journal of Real Estate Literature, 10(2), 223-242.

Shilling, J. D., Sirmans, C. F., \& Corgel, J. B. (1987). Price adjustment process for rental office space. Journal of Urban Economics, 22, 90-100.

Wheaton, W. C. (1987). The cyclic behavior of the national office market. AREUEA Journal, 15(4), 281299.

Wheaton, W. C., \& Torto, R. G. (1988). Vacancy rates and the future of office rents. Journal of the American Real Estate and Urban Economics Association, 16(4), 430-436. 